\title{
The implementation of probity audit to prevent fraud in public procurement of goods and services for government agencies
}

\author{
Johan Arifin*, Toni Hartadi \\ Universitas Islam Indonesia, Yogyakarta, Indonesia \\ ${ }^{*}$ Corresponding author email: johan.arifin@uii.ac.id
}

ARTICLE INFO

Article history:

Available online

Keywords:

Probity audit, procurement of goods

and services, national public

procurement agency (LKPP)

DOI:

https://doi.org/10.20885/jaai.vol24.is $\underline{\text { s1.art2 }}$
A B S T R A C T

The procurement activities to obtain goods and services for government agencies in Indonesia are susceptible to becoming a medium of various types of fraud. Probity audit is a novel approach in which real-time audit is implemented in the process of goods and services procurement to overcome ongoing fraud issues. This study aimed to evaluate the implementation of probity audit with reference to applicable regulations. This research was a descriptive qualitative study analyzed using the document analysis method. The object of the study was the Inspectorate of the National Public Procurement Agency (LKPP) as the Government Internal Supervisory Apparatus of LKPP. The study results showed that, first, the suitability of facilities and infrastructure to implement probity audit was fairly good; second, the implementation of probity audit was satisfactory and in accordance with the guidelines for probity audit; third, the issue during the implementation of probity audit included the absence of policy and Standard Operating Procedure (SOP) for the implementation of probity audit in LKPP. This research was also expected to become one of the relevant sources for future researchers and assist the government in implementing the probity audit policy in Indonesia.

\section{Introduction}

The process of goods/services procurement in a number of Indonesian government agencies is an activity subjected to an alleged misuse to commit various sorts of fraud. Research conducted by the Corruption Eradication Commission ${ }^{1}$ (KPK) in 2007 prior to the issuance of the goods/services procurement regulations revealed that corruption in goods/services procurement reached $70 \%$ of all corruption cases (Prayogo, 2017). In addition, a study by the Indonesian Corruption Watch (ICW) in 2017 indicated that corruption in the procurement of goods/services in Indonesia reached a relatively high level with $42 \%$ of all existing cases (detiknews, 2018). Considering the high level of corruption in goods/services procurement, the Indonesian government constantly makes considerable efforts to reduce the high corruption index in goods/services procurement. Different regulations and tremendous efforts have been made by the Indonesian government to decrease corruption cases, particularly relating to goods/services procurement in government agencies.

A new approach to audit called real-time goods/services procurement audit becomes an alternative that can be implemented by the government to overcome various issues related to the process of goods/services procurement, especially to detect fraud and irregularities. In the United States, such audit is known as pre-award audit (Earnhart \& Leonard, 2016), and in Australia it is named probity audit (Whittle et al., 2014). According to Thompson et al. (2015), one of the success factors in the process of public procurement is probity or, in other words, 'honesty'. Probity audit is an approach to prevent corruption and ensure that the process of all activities in a public sector agency, such as goods/services procurement, asset sales, and sponsorships/grants, is performed in a fair, objective, transparent, and accountable manner.

Probity audit is an independent appraisal activity to assure that the process of goods/services procurement has been consistently performed in line with the principles of integrity, truthfulness, and honesty as well as in compliance with the applicable laws and regulations to increase the accountability of the use of public funds. Probity audit is a real-time activity simultaneously performed with the goods/services procurement activities. The regulation for goods/services procurement is stipulated in Article 76 of the Presidential Regulation

\footnotetext{
${ }^{1}$ Formed with reference to Law No.30 of 2002. The Corruption Eradication Commission (KPK) is an institution that is given the mandate to eradicate corruption intensively, professionally, and continuously. KPK is an independent state institution, so that in carrying out its duties free from any party in power.
} 
No. 16 of 2018, in which a minister/head of agency/head of regional government is required to supervise the procurement of goods/services through an internal supervisory apparatus within the corresponding ministry/agency/regional government. Such supervision can be performed through an auditing, reviewing, monitoring, evaluating, and/or whistleblowing system (Wuysang et al., 2016). The supervisory actions taken in the process of goods and services procurement aim to support the government to eradicate abuse of power and acts of corruption, collusion, and nepotism (KKN) during such process. According to Fuddloilulhaq and Usman (2017), the control system in an organization for goods and services procurement by assigning the Government Internal Supervisory Apparatus ${ }^{2}$ (APIP) is a form of real-time inspection (probity audit).

Furthermore, according to Thompson et al. (2015), government transparency and accountability can be achieved through probity audit as is performed in Australia. Meanwhile, Whittle et al. (2014) revealed that efforts to prevent and detect possible fraud in an organization can be performed by involving internal auditors. The implementation of probity audit as an effort to prevent fraud during the process of goods/services procurement for government agencies has been regulated by the Finance and Development Supervisory Agency (BPKP) as the national government internal auditor in Indonesia. This agency has the mandate to oversee the process of goods/services public procurement and become an early warning system for the procurement process. The implementation of probity audit is also in line with the goals of the government to improve the quality of state accountability, which is related to effective, efficient, transparent, and accountable management of state finance and in line with the efforts from the government to accelerate corruption eradication as stipulated in the Presidential Instruction No. 5/2004 updated in the Presidential Instruction No. 1 of 2013. Probity audit is regulated in the Regulation of the Head of BPKP in PER-362/K/D4/2012 regarding the Guidelines for Probity Audit of Goods/Services Procurement for the Government Internal Supervisory Apparatus (APIP). The regulation stipulates the criteria for a project that can be approached using probity audit, including high-risk and complex work packages, work packages associated with a controversial history/background or legal issues, politicallysensitive work packages, work packages with the potential to cause conflicts of interest, work packages related to public interest, work packages to meet basic community services, and work packages with relatively higher value compared to that of other work packages (LKPP, 2016).

Ramadhan and Arifin (2019) and Fuddloilulhaq and Usman (2017) stated that fraud in organizations, particularly in the audit of goods or services procurement, can be prevented by implementing the probity audit approach. The principles of such approach include actions to evade conflicts, avoid KKN, make improvement with the aim of enhancing the integrity of public sectors by changing organizational behavior, convince the society that all public sector activities have been performed with high-integrity and reliable processes, in an objective and independent manner for honesty (probity) during the process of goods and services procurement, as well as reduce legal actions. A number of regulations have been stipulated by the government to reduce corruption in the process of goods/services procurement. The government's effort to issue guidelines on the implementation of probity audit indicates their earnest effort to prevent corruption.

The National Public Procurement Agency (LKPP) is a government agency whose duty is to develop and formulate a policy on goods/services public procurement. LKPP was established based on the Presidential Regulation No. 106 of 2007 regarding the National Public Procurement Agency, recently amended by the Presidential Regulation No. 157 of 2014 regarding the Amendment to the Presidential Regulation No. 106 of 2007 regarding the National Public Procurement Agency. In performing their duties and functions, LKPP works under the coordination of the State Minister for National Development Planning/Head of National Development Planning Agency (Bappenas). Specifically, the function and authority of LKPP include the implementation of good governance in goods/services public procurement. The Inspectorate of LKPP as the Government Internal Supervisory Apparatus (APIP) is obliged to perform probity audit tasks to guarantee that work package procurement has been implemented in accordance with the applicable procedures and standards. LKPP as the policy-making institution of goods/services public procurement is expected to become a benchmark for the effective implementation of probity audit. Based on the aforementioned background and problem explanation in relation to the implementation of guidelines for the probity audit of goods/services procurement in government agencies as well as on the fact that a large number of corruption cases occur in goods/services procurement, it is therefore necessary to evaluate the implementation of probity audit with the Inspectorate of LKPP as the research object.

The success of procurement process is determined by an appropriate planning (Nzimand \& Padayachee, 2017). When procurement planning is not well prepared, various problems can arise during the contract implementation. A large number of contract implementations run into problems relating to both civil and criminal proceedings due to poor planning. Various government agencies in Indonesia have in fact experienced such problems, especially in processing procurement contracts (Tan, 2017). The probity audit performed by the government internal auditor is expected to prevent a loss of state finance.

\footnotetext{
${ }^{2}$ Government Internal Supervisory Apparatus (APIP) is a Government Agency that has the main task and function of conducting supervision, therefore, the administration of government runs in accordance with the expected goals and targets.
} 
In line with the abovementioned background, the research problems can be formulated as follows: 1) Have the facilities and infrastructure for implementing probity audit in the Inspectorate of National Public Procurement Agency been adequate? 2) Has the implementation of probity audit by the Inspectorate of National Public Procurement Agency been in accordance with the guidelines on probity audit of goods/services procurement? 3) What are the problems encountered by the audit team in implementing probity audit in the Inspectorate of National Public Procurement Agency?

Based on the problem formulation, the research objectives include identifying the suitability of facilities and infrastructure for implementing probity audit at the Inspectorate of National Public Procurement Agency as well as identifying whether the probity audit conducted by the Inspectorate of National Public Procurement Agency has been in accordance with the guidelines for probity audit of goods/services procurement.

\section{Literature Review}

\section{Agency Theory}

The agency theory suggests that if the agent has advantages in terms of information and interests as opposed to the principal, it will pose problems to both parties as the agent will take some self-beneficial measures which on the other hand will harm the other party, or the principal. Both parties will be involved in a conflict of interest, ultimately resulting in agency cost (Gudono, 2012; Panda \& Leepsa, 2017; Rashid, 2016). Meanwhile, theory provides analytical insights to study the impacts of the relationship between agent (manager) and principal (shareholders), or between principal (shareholders) and principal (lenders). A conflict of interest between the principal and agent can result from the actions taken by the agent with contrary interests to those of the principal and in the end will lead to agency cost. Managers have a moral responsibility to maximize profits for shareholders to be rewarded according to the agreement. Shogren et al. (2017) used three assumptions of human nature to explain the agency theory, in which human beings are innately selfish, have limited power to think of the perceived future, and always avoid risks. Based on such assumptions, it is concluded that, as human being, managers have a strong probability of taking opportunistic actions, especially those concerned with personal interests (Bird et al., 2018).

The implementation of goods and services procurement in Indonesia can be classified based on the involving parties, namely the government as a budget user, or the principal, and a third party as the provider of goods/services (the agent). There have been a number of studies conducted, such as by Ribeiro et al. (2017), Araujo and Tejedo-Romero (2016), and Caruana and Giorgia (2017), which revealed that both the government and third party are often involved in different interests that can result in a loss of finance, time, energy, and specifications for the procurement of goods or services which are not in accordance with the agreement.

\section{Theory of Planned Behavior}

According to Oni et al. (2017), the Theory of Reasoned Action (TRA) is used to study human behavior and to develop factors that can influence human behavior. TRA starts by observing the intention to behave as the nearest antecedent of behavior. The Theory of Reasoned Action is most successful when applied to behavior under the control of the individual himself. If the behavior is not entirely under the control or will of the individual, even though the individual is highly motivated by his attitudes and subjective norms, he may not actually display the behavior. Problems related to TRA will arise if the theory is applied to behavior that is not completely under the control of an individual. Various studies performed using TRA found a number of weaknesses including what has been previously mentioned. To fix these weaknesses, a new construct named perceived behavioral control is added to TRA. Such construct is added as an effort to understand the limitations of an individual to perform certain behavior. In other words, whether or not intent and behavior are executed is determined not only by attitudes and subjective norms but also by individual perception of the control which can come from his belief in such control (control beliefs) (Caldwell \& Holloway, 2017).

Intent can be expressed through the Theory of Planned Behavior (TPB), namely intention or attitude to behave, subjective norms, and behavioral control (Roos \& Hahn, 2019). The formation of intentions plays a unique role in directing actions that is to connect the perceived to the desired in-depth considerations of an individual with certain actions (Putra et al., 2018). In general, the factor of intense antecedent can be explained by the theory of planned behavior which assumes that human beings always have an intention to behave (Bird et al., 2018).

\section{Fraud Triangle Theory}

A large number of experts express their opinions about the concept of the causes of fraud. One of the concepts widely used in the practice of accounting is the concept of fraud triangle. This theory suggests that fraud occurs due to three elements, including pressure, opportunity, and rationalization. These three elements of fraud exist 
together at different levels in an organization and affect each individual differently (Ruankaew, 2016). This theory is later developed schematically by the Association of Certified Fraud Examiners (ACFE). ACFE describes fraud in a fraud tree usually presented in a chart. Fraud tree has three main branches called corruption, asset misappropriation, and fraudulent statements (Tuanakotta, 2016).

Fraud triangle can become a strategy to prevent corruption in the procurement of goods and services by identifying corrupt behavior. If the cause is the pressure at work, then preventive action needs to be taken to minimize or even eliminate the pressure (Said et al., 2018). Pressure in the work environment can be caused by the imbalance between workload and earned income. On the other hand, if corruption is triggered by an opportunity due to weak internal control, the Government Internal Control System (SPIP) can be effectively implemented.

\section{Goods and Services Public Procurement}

Goods and services procurement in government agencies is a fundamental component of good governance. Such procurement aims, among others, to obtain goods and services at an accountable price with appropriate quality and amount of time as well as punctuality (Arsana, 2016). Procurement of goods/services in government agencies is an action taken by the government starting from the Commitment-Making Officials ${ }^{3}$ (PPK) and Selection Working Group ${ }^{4}$ to obtain goods/services using processes and methods with some requirements to reach agreement on the price, time, and quality of goods/services.

An audit of goods/services procurement planning starts from an audit of goods/services need identification and their budgeting during the preparation of General Procurement Plan (RUP) based on the existing records or an incidental survey. An audit of the preparation for goods/services selection includes auditing the procurement organization, plan for the selection of goods/services provider, procurement system, schedule for the selection of goods/services provider, owner estimate, and preparation of procurement documents. These guidelines are completed with detailed program audits and a list of assessments to assist the process of drawing conclusions. However, the audit working paper still has to be prepared by auditors to enforce compliance with the audit standards. The assessment list only serves as guidelines and not as a substitute for audit working paper.

\section{Roles of Inspectorate in the process of goods/services procurement}

Based on the Government Regulation No. 60/2008 regarding the Government Internal Control System, it is explained that the embodiment of the effective roles of the Government Internal Supervisory Apparatus (APIP) includes (1) building a sufficient level of confidence in the compliance, frugality, efficiency, and effectiveness to achieve the goals of executing the tasks and functions of government agencies, (2) providing an early warning and improving the effectiveness of risk management in executing the tasks and functions of government agencies, and (3) maintaining and improving the quality of good governance in executing the tasks and functions of government agencies.

This also includes the implementation of goods/services procurement as one of the activities conducted by government agencies. One of the procedures carried out by the inspectorate to build an adequate level of confidence in goods/services procurement is to conduct an audit of goods/services procurement. An audit of goods/services procurement by the inspectorate can build an adequate degree of confidence that the process of goods/services procurement has been running effectively, efficiently and accountably (Syukron, 2017).

\section{Probity Audit}

Probity is defined as integrity, uprightness, and honesty. The concept of probity is used not only to prevent corruption or fraud but also to ensure that the process of managing public sector activities, such as the process of goods/services procurement, asset sales, and sponsorship/grants, is performed in a fair, objective, transparent and accountable manner (BPKP, 2012). Probity audit is an independent assessment activity with the aim of ensuring that the procedures of goods/services procurement are implemented consistently and in accordance with the principles of integrity, uprightness, and honesty as well as in compliance with the applicable laws and regulations to increase accountability in the use of public sector funds.

Probity audit is mainly applied to strategic work packages (involving community interests, constituting basic community services, and relating to political issues). Probity audit is implemented simultaneously during the process of goods/services procurement or immediately after the process of goods/services procurement (real-time

\footnotetext{
${ }^{3}$ Commitment-Making Officials (PPK=Pejabat Pembuat Komitmen) are officials who are authorized by the Budget User/Budget User Authority to make decisions and/or take actions that can result in the expenditure of the state or regional budget. Therefore, the PPK is responsible administratively, technically and financially for the procurement of goods/services.

${ }^{4}$ Selection Working Groups (Pokja Pemilihan) are human resources determined by the leaders of the Procurement Working Unit to manage the selection of providers.
} 
audit). Therefore, the preferable probity audit techniques include a physical review, observation, discussion, and interview without neglecting other audit techniques (BPKP, 2012).

Probity means honesty, integrity, and uprightness. The concept of probity is used not only to prevent corruption or fraud but also to ensure that the procedures of public sector activities, such as goods/services procurement, asset sales, and sponsorship/grants, are applied in a fair, objective, transparent/open, and accountable manner. Meanwhile, $\mathrm{Ng}$ et al. (2018) provided an abstraction of probity audit, stating that: "... Probity audits refer to independent reviews of government privatization, contracting out projects (government procurements), and expressions of interests to ascertain whether procedures are followed with consistent regulations, guidelines and best practice principles of openness and transparency". Meanwhile, according to the National Government Procurement Agency, probity audit is an independent appraisal activity conducted to assess whether the process of goods/services procurement is in compliance with the standard procedures, fair, accountable, and transparent (LKPP, 2016).

The implementation of probity audit focuses on the aspect of compliance with procedures and real-time processes/systems rather than post-audit. Probity audit is performed to protect strategic work processes that involve community interests, a large amount of funding from the community, and strongly associated with political issues (Jung et al., 2017). The process of probity audit involves a physical review, discussion, observation, and interview as well as other audit techniques. Probity audit should be based on the principles of Goods and Services Procurement (PBJ) in the Presidential Regulation No. 16 of 2018. The targets of PBJ probity audit require that the procurement is carried out punctually with high quality, resulting in advantageous procurement values for the country and society. Second, the implementation of PBJ is appropriately in compliance with the laws and regulations. Third, the quantity, quality, and price are obtained through a process that is relevant to the agreement stated in the contract, and the handover of work is conducted punctually. Fourth, building a good sense of confidence that the goods have been located in the appropriate place and properly justified according to the intended use is required. Fifth, the weaknesses in PBJ are identified to improve the system.

The probity audit report should present the objectives, scope, and results of probity audit, including the probity auditor's opinion. The report should highlight significant findings and recommendations as well as inform the management of any fraud found in the agreed process along with the reasons for such fraud. Changes in public sector management prioritize value for money. One of the authentic implementation of public sector management or accounting is when the government prepares accountability reports for the interests of the government itself (internal) and not for the public while the government manages public funds or money (Sinaga, 2017).

\section{Fraud in Probity Audit}

Zuberi and Mzenzi (2019) stated that the cause or root of fraud issues is fraud by need, fraud by greed, and fraud by opportunity. If an institution is open in resolving fraud then when there is an indication of fraud within the institution, it can openly provide information related to the fraud occurring within the institution. This will give a deterrent effect, and an individual will think twice when intending to take the same action. Nawawi and Salin (2018) stated that fraud can be prevented by activating internal control. The types of fraud frequently encountered in the process of goods/services procurement include discrepancy between the goods/services agreed in the contract and the demand of agencies and/or the public in terms of the type, quality, and quantity of the goods/services, mismatch between the technical specifications of goods/services completed by the provider and those specified in the agreement/contract, difference between the volume (quantity) of goods/services established by the provider and the quantity listed in the agreement/contract, abnormality of goods/services prices compared to those agreed in the contract/agreement, and delay in the completion of work by the provider apart from the schedule specified in the agreement/contract.

The expected output from the implementation of probity audit for goods/services procurement is a report on the audit results which provides information about the conclusions and opinions based on the appraisal of goods/services procurement regarding the efficient, effective, open and competitive, transparent, fair/nondiscriminatory, and accountable principles. Meanwhile, the outcome is the use of audit report in the decision making process by the central government, regional governments and directors of BI/BHMN/BUMN/BUMD/other business entities to improve the planning, implementation, and control of goods/services procurement activities to be more efficient, effective, open and competitive, transparent, fair/non-discriminatory, and accountable (BPKP, 2012).

\section{Research Methods}

This research was a descriptive study with a qualitative approach, which was a study that sought to describe and interpret objects as they were. The evaluation data collected from interviews and documentation were analyzed 
and evaluated based on the criteria determined using a descriptive qualitative analysis. The analysis used in this research was the document analysis. The selected interview model was the semi-structural interview to obtain a more open interview process, in which the interviewed participants were asked for their opinions and ideas. Furthermore, data analysis was performed based on the interview transcript analysis. The interview participants consisted of auditors in the Inspectorate of LKPP, Catalog Working Group ${ }^{5}$ (Pokja Katalog), Management of LKPP Inspectorate, as well as Structural Officers and Inspectors of LKPP. The collected data were then analyzed, described, and developed into a description and discussion. The following stage was the validity test and test of the study results. The validity test was conducted using the source triangulation. In such process of source triangulation, the researcher compared the information or data obtained from different sources or participants.

The analysis method used in this research was the descriptive analysis. The research process consisted of two phases, namely the development of an initial research model and the qualitative approach. The writing procedures to collect and analyze the research data included (1) literature study, (2) mapping the procedures and activities of probity audit, (3) determining the criteria of each audit procedure, (4) conducting data analysis in the Data Collection Matrix, and (5) scoring each audit procedure stage in the Implementation Assessment Matrix for Probity Audit. These procedures referred to previous research conducted by Fuddloilulhaq and Usman (2017).

\section{Description of Research Participants}

\section{Participant 1}

Mr. Angga is a structural officer of LKPP Inspectorate as the Head of the Administration Subdivision. Based on the Regulation of the Head of LKPP No. 4 of 2017 regarding the Organization and Administration of the National Public Procurement Agency, the tasks of the Administration Subdivision include administrative affairs, financial administration, internal affairs, equipment, personnel administration, as well as organization and governance within the scope of the Inspectorate. In his capacity, Participant 1 understands the implementation and documentation of probity audit archives performed by LKPP Inspectorate.

\section{Participant 2}

Mrs. Estu is an executive of LKPP Inspectorate as a prospective auditor who has completed the Auditor Candidate Education and Trainings. In this study, the researcher discussed with and interviewed Participant 2 about the implementation of probity audit. Furthermore, the researcher and participant jointly observed the archive documentation of probity audit implementation.

\section{Participant 3}

Mr. Didi is an auditor seconded from the Finance and Development Supervisory Agency (BPKP). In his assignment at the LKPP Inspectorate, Participant 3 was frequently assigned as the Head of Audit Team/Technical Controller. The researcher conducted a discussion and interview with Participant 3 concerning the implementation of probity audit based on the applicable regulations.

\section{Participant 4}

Mrs. Ayu is an auditor seconded from the Finance and Development Supervisory Agency (BPKP). In her assignment at the LKPP Inspectorate, Participant 4 was frequently assigned as the Head of Audit Team/Technical Controller. The researcher conducted a discussion and interview with Participant 4 concerning the implementation of probity audit based on the applicable regulations.

\section{Participant 5}

Mr. Satrio is a structural officer in the General and Financial Bureau of LKPP as the Head of the Inventory and Disposal of State Property Subdivision. Participant 5 is a member of the Catalog Working Group who conducts a probity audit at the selection stage. The researcher discussed with and interviewed Participant 5 about the implementation of probity audit.

\section{Participant 6}

Mr. Angga is a structural officer at the LKPP Inspectorate as the Head of the Administration Subdivision. Participant 6 is a member of the Catalog Working Group conducting a probity audit at the selection stage. The researcher conducted a discussion and interview with Participant 6 relating to the implementation of probity audit.

\footnotetext{
${ }^{5}$ Catalog Working Group (Pokja Katalog) has the task of delivering goods/service catalog information related to the process of procurement goods/services of government agencies.
} 


\section{Participant 7}

Mr. Peter is an LKPP Inspector. The researcher interviewed and confirmed Participant 7 about the findings of the study concerning the implementation of probity audit at LKPP Inspectorate.

\section{Results and Discussion}

\section{Facilities and Infrastructure for Probity Audit at LKPP Inspectorate}

The suitability of probity audit procedures performed by LKPP Inspectorate based on the evaluation of audit preparation stage, implementation stage, and reporting stage was very adequate. This indicates that the suitability of facilities and infrastructure for conducting probity audit at LKPP Inspectorate is fairly satisfactory. The facilities and infrastructure referred to herein include the utilization of facilities and infrastructure for implementing probity audit, such as operating the tools and equipment for auditing. This also covers any activities performed from the preparation stage through to the reporting stage. In relation to such matter, Parker et al. (2019) stated that in each utilization of facilities and infrastructure for probity audit, the key principles of being efficient and effective, transparent and open, fair/non-discriminatory, and accountable should be applied. Another finding closely related to the use of facilities and infrastructure was the quality of human resources, in which not all probity auditors held a professional certificate in probity audit. This requires special attention to ensure that in the future all probity auditors can be expected to have a professional certificate, especially in the field of probity audit. If an auditor passes a probity audit professional certification, he is considered to have the competency to conduct a probity audit. This is consistent with the statement of Brown et al. (2016) and Ruiz-Molina et al. (2019) that the level of competency in a professional field will affect the success of task implementation in the field concerned.

\section{Suitability of Probity Audit Implemented by LKPP Inspectorate with the Guidelines for Probity Audit of Goods/Services Procurement}

The implementation of probity audit by LKPP Inspectorate was fairly good, but LKPP had yet to establish a regulation concerning the probity audit policy in the process of goods/services public procurement in LKPP. The ongoing probity audits fully refer to the Regulation of the Head of BPKP No. PER-362/K/D4/2012 regarding the Guidelines for Probity Audit of Goods/Services Procurement for APIP. Overall, the suitability of probity audit by the Inspectorate of LKPP with the guidelines based on the implementation assessment matrix reached 0.9504 out of 1.0000. This shows that the implementation of probity audit is "highly adequate".

The preparation stage is the initial stage of probity audit. This stage consists of audit request, setting of objectives, scope, and methodology, allocation of resources, preparation of audit working programs, and issuance of the letter of assignment. Based on the evaluation of the suitability of probity audit with the Guidelines for Probity Audit of Goods and Services Public Procurement conducted by LKPP inspectorate, the preparation stage reached a value of 0.27 out of 0.30 , achieving $89.29 \%$. This indicates that the preparation stage has been carried out "very adequately".

The implementation phase is the key stage of probity audit. This stage consists of preliminary discussion with the audits (entry meeting), implementation of detailed program and assessment list audit, preparation of audit working papers, supervision of audit implementation, communication of audit results, and follow-up of audit results. Based on the evaluation of the suitability of probity audit with the Guidelines for Probity Audit of Goods and Services Public Procurement by LKPP Inspectorate, the implementation stage gained a value of 0.57 out of 0.60 with an achievement of $95.83 \%$. These results indicate that the implementation stage by the LKPP Inspectorate has been performed in a "very adequate" manner.

The reporting stage is the final stage of probity audit. This stage includes preparing an audit report (LHA) and its distribution. Based on the evaluation of the suitability of probity audit with the Guidelines for Probity Audit of Goods and Services Public Procurement by LKPP Inspectorate, the reporting stage obtained a value of 0.10 out of 0.10 with $100 \%$ achievement. This shows that the reporting stage by LKPP Inspectorate has been performed in a "very adequate" manner.

Results of interview regarding the policy of probity audit: (statement from Participant 1)

"So far, we refer to the Regulation of the Head of BPKP No. 362. LKPP does not have its own policy related to the implementation of probity audit. It was a coincident during the implementation of probity audit, the panel team leader was Mrs. Rita as an LKPP Inspector who was also a member of the Regulation of the Head of BPKP 362 compiler team. Therefore, the auditors gained numerous benefits as they were directly guided by a compiler of probity audit policy."

A similar opinion was also expressed by Participant 2 who stated that LKPP did not yet have a policy on probity audits at LKPP. Participant 2 said that: 
"I don't think there is yet, sir, we are using the Regulation of the Head of BPKP No. 362. Overall, we fully refer to the Regulation of the Head of BPKP 362 in conducting probity audit, starting from planning, implementation, and reporting. Perhaps this is because we were only established in 2015, sir, so the policy has not yet been made. However, when conducting internal audits, we are still guided by the SAIPI."

Meanwhile Participant 7 confirmed that LKPP did not yet have a policy on implementing probity audit at LKPP, he stated:

"In the LKPP Inspectorate there is no such policy, right? Alright I accept the evaluation, and the policy will be immediately prepared in LKPP."

The results of these interviews indicate that LKPP has not yet had specific regulations related to the probity audit policy in the procurement of goods and services. Policy is a series of concepts that contain general instructions about the implementation of an activity (Tadeusz \& Tadeusz, 2018). Heidenreich et al. (2018) further stated that the established policy will provide assurance and continuity of the administrative tasks and functions within an organization. In relation to the implementation of probity audit, a policy should therefore be established by each government agency as guidelines for the implementation of probity audit. It is expected that BPKP as a guiding agency for the Government Internal Supervisory Apparatus (APIP) in Indonesia to expand the dissemination of the Regulation of the Head of BPKP No. 362/K/D4/2012 regarding Guidelines on the Probity Audit of Goods and Services Procurement for APIPs in all Ministries/Agencies/Regional Governments/other Institutions $(\mathrm{K} / \mathrm{L} / \mathrm{D} / \mathrm{I})^{6}$ and to initiate the harmonization of probity audit policies. Therefore, the harmonization of policies among K/L/D/I, one of which is at the Ministry of Home Affairs, will provide assurance of the probity audit guidelines for regional governments in Indonesia, given the high value of goods and services procurement in regional governments to make the implementation of probity audit more affective.

\section{Issues in Probity Audit Implementation at LKPP Inspectorate}

Based on the observations and documentation reviews, there was a problem related to the limited number of auditors at LKPP Inspectorate. Consequently, in the implementation of probity audit, the formal requirements of an auditor in an audit team were not fully met. The interview results led to a conclusion that there were no communication issues between the Catalog Working Group and the auditors. The data requested by the auditors could be immediately provided by the Catalog Working Group; however, there was another issue in which the Ministry of Health technical team was absent during the probity audit, causing a difficulty for the Catalog Working Group when the auditor asked about technical issues, such as drug structures or drug types, due to the limited knowledge among the Catalog Working Group members.

The following findings come from the interview:

Regarding the interpersonal communication, Participant 6 argues that:

"Since the goals have been set by the leader, there are no issues of interpersonal communication with the auditors. We also convey the data request quickly because the goals of probity audit have been submitted by the leader."

In line with the statement of Participant 6 about the absence of communication issues between the Catalog Working Group and the auditors, Participant 5 stated:

"There is nothing to say from me because it has been conveyed by the leader that the purpose of this probity audit is to comply with the regulations and to run against time."

Participant 5 added more technical issues other than the communication issue with the auditors:

"The technical team from the Ministry of Health should be involved in this probity audit activity in tandem because we don't know the structure of drugs. The problem is that when the probity audit team asks us, we don't really know. The technical team from the Ministry of Health should be present at all stages of probity audit. We have actually invited, but only the staff members were present."

From the interview, it is seen that there are no issues related to communication with the auditors. However, the absence of the Ministry of Health technical team when the probity audit process was carried out demanded the establishment of a Standard Operating Procedure (SOP) that strictly regulates the rights and obligations of each party involved in a probity audit. According to Dirnagl (2010), SOP is a written guide (document) used to encourage and move an organization to achieve its goals. Therefore, the SOP should contain a complete set of work orders or stages to follow. A good SOP should contain a work process, who is responsible, and what documents are used. Furthermore, Musa and Clif (2018) revealed that in SOP there should be a number of criteria and standard quality, including quality, quantity, cost, and delivery time to fulfill.

\footnotetext{
${ }^{6}$ K/L/D/I: Kementerian/Lembaga/Pemerintah Daerah/Instansi Lain (Ministries/Agencies/Regional Governments/other Institutions)
} 
In addition, the SOP of probity audit implementation is expected to increase the quality of probity audit because SOP provides administrative work standards to prevent variations in the steps of working activities. This will create uniformity of actions even though the work is carried out by different people and in different areas. Furthermore, Khairunnisa et al. (2020) added that SOP can also be used to measure auditor performance by comparing the way the auditor works and the results with an existing SOP manual. SOP as part of the system is indeed an essential supporting tool in maintaining quality because, without SOP, an officer performing a probity audit can use his own non-standard methods in the process of his work.

\section{Conclusion}

The expected purpose of this research is to analyze the facilities and infrastructure for probity audit, implementation of probity audit for the procurement of goods and services, and issues in the implementation of probity audit. The suitability of probity audit stages by LKPP Inspectorate based on the evaluation of audit preparation stage, audit implementation stage, and audit reporting stage has been very adequate. This shows that the suitability of facilities and infrastructure for conducting probity audits at LKPP Inspectorate is fairly good. Auditor competency is highly necessary for a probity auditor in an appraisal, particularly for a more specific appraisal like probity audit. According to the Regulation of the Head of BPKP regarding guidelines for implementing probity audit, it is clear that a probity auditor is required to have ideal criteria, including personal and formal requirements. However, there is one ideal criterion that does not comply with the guidelines for implementing probity audit since not all members of the audit team assigned have a professional certificate, especially in the field of probity audit.

The implementation of probity audit by LKPP Inspectorate was fairly good. However, LKPP does not yet have regulations on the probity audit policy for the process of goods/services public procurement in LKPP. To perform a probity audit, LKPP fully refers to the Regulation of the Head of BPKP No. PER-362/K/D4/2012 regarding the Guidelines for Probity Audit of Goods/Services Procurement for APIP. Overall, the suitability of probity audit by LKPP Inspectorate with the guidelines based on the implementation assessment matrix reached 0.9504 out of 1.0000 . This shows that the probity audit was implemented in a "very adequate" manner.

The research conclusion relating to the issues of probity audit implementation by LKPP shows no issues during the probity audit. However, there was an issue with the auditee (Catalog Working Group) that had limited knowledge of a specific drug procurement package in a probity audit, which was closely related to the technical team of the Ministry of Health who could not always attend the probity audit. Therefore, it is necessary to stipulate a Standard Operating Procedure (SOP) related to the implementation of probity audit that clearly regulates the rights and obligations of each party involved in the probity audit.

\section{References}

Arsana, I. P. J. (2016). Manajemen Pengadaan Barang dan Jasa Pemerintah. Deepublish.

Bird, E. L., Panter, J., Baker, G., Jones, T., \& Ogilvie, D. (2018). Predicting walking and cycling behaviour change using an extended Theory of Planned Behaviour. Journal of Transport \& Health, 10, 11-27.

BPKP. (2012). Peraturan Kepala Badan Pengawasan Keuangan dan Pembangunan Nomor: per- 362/k/04/2012, tentang Pedoman Probity Audit Pengadaan Barang/Jasa Pemerintah Bagi Aparat Pengawasan Intern Pemerintah. BPKP.Jakarta.

Brown, V. L., Gissel, J. L., \& Neely, D. G. (2016). Audit quality indicators: perceptions of junior-level auditors. Audit Quality Indicators: Perceptions of Junior-Level Auditors, 31(8/9), 949-980.

Caldwell, C., \& Holloway, C. S. (2017). Trust, faith, and commitment: A reasoned action approach. Business and Management Research, 6(3), 52-57.

Caruana, J., \& Giorgia, M. (2017). inancial reporting principles for smaller Public Entities: the case of the Maltese local government. Journal of Modern Accounting and Auditing, 13, 435-450.

detiknews. (2018, February 25). ICW: Korupsi Pengadaan Barang 2017 Meningkat, Negara Rugi Rp 1 T. Detik.Com. https://news.detik.com/berita/d-3885311/icw-korupsi-pengadaan-barang-2017-meningkatnegara-rugi-rp-1-t

Dirnagl, U. (2010). Quality control and standard operating procedures. Rodent Models of Stroke, 47, 239-248.

Earnhart, D., \& Leonard, J. M. (2016). Environmental audits and signaling: The role of firm organizational structure. Resource and Energy Economics, 44, 1-22.

Esteves de Araujo, J. F. F., \& Tejedo-Romero, F. (2016). Local government transparency index: determinants of 
municipalities' rankings. https://doi.org/10.1108/JEBR-02-2016-0064

Fuddloilulhaq, M., \& Usman, F. (2017). Evaluasi kesesuaian pelaksanaan probity audit pada BPKP pusat dengan pedoman probity audit pengadaan barang/jasa pemerintah. Jurnal Info Artha, 1(1), 17-34.

Gudono. (2012). Teori Organisasi (2nd ed.). BPFE.

Heidenreich, M., Hiller, P., \& Dörhöfer, S. (2018). Redesigning Organizational Boundaries and Internal Structures: A Sociological Interpretation of Activation Policies. Toward Permeable Boundaries of Organizations?, 57, 169-193.

Jung, C. S., Chun, Y. H., \& Ho, J. R. (2017). Examining relationships between legislative and presidential influences and organizational probity: Evidence from South Korean central government agencies. International Public Management Journal, 20(1), 132-159.

Khairunnisa, Latief, Y., \& Riantini, L. S. (2020). Standard operational procedure (SOP) auditing process in integrated management system to improve the efficiency of organizational performance. The 3rd International Conference on Eco Engineering Development, 1-8.

LKPP. (2016). Buku Informasi Evaluasi Kinerja Pengadaan Barang/Jasa. Lembaga Kebijakan Pengadaan Barang dan Jasa Pemerintah (LKPP).

Musa, N., \& Clif, B. (2018). Internal control and standard operating procedures in Malaysian corporations. Journal of Telecommunication, Electronic and Computer Engineering, 9(2), 25-31.

Nawawi, A., \& Salin, A. S. A. P. (2018). Internal control and employees' occupational fraud on expenditure claims. Journal of Financial Crime, 25(3), 891-906.

Ng, H. Y., Tronnes, P. C., \& Wong, L. (2018). Audit seasonality and pricing of audit services: Theory and evidence from a meta-analysis. Journal of Accounting Literature, 40, 16-28.

Nzimand, N., \& Padayachee, P. (2017). Evaluation of the current procurement planning process in a district municipality. International Journal of Public Policy and Administration Research, Conscientia Beam, 4(1), 19-34.

Oni, A. A., Oni, S., Mbarika, V., \& Ayo, C. K. (2017). Empirical study of user acceptance of online political participation: Integrating Civic Voluntarism Model and Theory of Reasoned Action. Government Information Quarterly, 34(2), 317-328.

Panda, B., \& Leepsa, N. M. (2017). Agency theory: Review of theory and evidence on problems and perspectives. Indian Journal of Corporate Governance, 10(1), 74-95.

Parker, L. D., Jacobs, K., \& Schmitz, J. (2019). New public management and the rise of public sector performance audit: Evidence from the Australian case. Accounting, Auditing \& Accountability Journal, 32(1), 280 306.

Prayogo, S. (2017). Rekonstruksi pengadaan barang dan jasa yang dilaksanakan oleh badan usaha milik negara berbasis nilai keadilan islam. Univesitas Islam Sultan Agung.

Putra, K. N., Triyuwono, I., \& Purwanti, L. (2018). Fraud procurement of goods and services a perspective of the Theory of Planned Behavior. Jurnal Akuntansi, 22(3), 385-404.

Ramadhan, M. S., \& Arifin, J. (2019). Efektivitas probity audit dalam mencegah kecurangan pengadaan barang dan jasa. Jurnal Akuntansi Multiparadigma, 10(3), 550-568.

Rashid, A. (2016). Managerial ownership and agency cost: Evidence from Bangladesh. Journal of Business Ethics, 137, pages609-621.

Republik Indonesia. 2004. Peraturan Presiden Nomor 5 tahun 2004 tentang Pembentukan Tim Penilai Akhir Pengangkatan, Pemindahan, Dan Pemberhentian Dalam Dan Dari Jabatan Struktural Eselon I. Sekretariat Negara. Jakarta.

Republik Indonesia. 2007. Peraturan Presiden Nomor 106 tahun 2007 Tentang Lembaga Kebijakan Pengadaan Barang/Jasa Pemerintah. Sekretariat negara. Jakarta.

Republik Indonesia. 2008. Peraturan Pemerintah Republik Indonesia Nomor 60 Tahun 2008 Tentang Sistem Pengendalian Intern Pemerintah. Sekertariat Negara. Jakarta

Republik Indonesia. 2013. Peraturan Presiden Nomor 1 Tahun 2013 Pengesahan Perjanjian Antara Republik 
Indonesia Dan Republik Portugal Tentang Pembebasan Visa Tinggal Jangka Pendek Untuk Pemegang Paspor Diplomatik, Dinas Dan Khusus. Sekretariat Negara. Jakarta.

Republik Indonesia. 2014. Peraturan Presiden Nomor 157 Tahun 2014 Tentang Perubahan Atas Peraturan Presiden Nomor 106 Tahun 2007 Tentang Lembaga Kebijakan Pengadaan Barang/Jasa Pemerintah. Sekretariat Negara. Jakarta.

Republik Indonesia. 2018. Peraturan Presiden Nomor 16 Tahun 2018 tentang Pengadaan Barang/Jasa Pemerintah. Sekretariat Negara. Jakarta.

Ribeiro, N., Nogueira, S., \& Freitas, I. (2017). Transparency in Portuguese local government: A study of its determinants PDF Logo. European Financial and Accounting Journal, 12(3), 191-202.

Roos, D., \& Hahn, R. (2019). Understanding collaborative consumption: An extension of the Theory of Planned Behavior with value-based personal norms. Journal of Business Ethics, 158(3), 679-697.

Ruankaew, T. (2016). Beyond the Fraud Diamond. International Journal of Business Management and Economic Research, 7(1), 474-476.

Ruiz-Molina, M.-E., Gil-Saura, I., Berenguer-Contri, G., \& Auch, C. (2019). eterminants of behavioral intentions towards a professional certification scheme at European level. European Journal of Training and Development, 43(7), 719-735.

Said, J., Alam, M. M., Karim, Z. A., \& Johari, R. J. (2018). Integrating religiosity into fraud triangle theory: findings on Malaysian police officers. Journal of Criminological Research, Policy and Practice, 4(2), $111-$ 123.

Shogren, K. A., Little, T. D., \& Wehmeyer, M. L. (2017). Human agentic theories and the development of selfdetermination. In Development of Self-Determination Through the Life-Course (Developmen, pp. 1726). Springer.

Sinaga, J. (2017). Peranan akuntansi manajemen sektor publik menuju good governance di Indonesia. Jurnal Ilmiah Methonomi, 3(2), 164-168.

Syukron, A. M. (2017). Analisis peran inspektorat daerah kabupaten Bantul dalam pengawasan proses pengadaan barang/jasa. Universitas Gadjah Mada.

Tadeusz, K., \& Tadeusz, M. (2018). The territorial capital of urban functional areas as a challenge for regional development policy: An outline of the concept. Zarzadzanie Publiczne / Public Governance, 44(2), 4155.

Tan, E. (2017). Analisis sistem dan prosedur pengadaan kebutuhan farmasi pada RSUD Sultan Syarif Mohamad Alkadrie Pontianak. Jurnal Audit Dan Akuntansi Fakultas Ekonomi, 6(2), 63-84.

Thompson, N., Ravindran, R., \& Nicosia, S. (2015). Government data does not mean data governance: Lessons learned from a public sector application audit. Government Information Quarterly, 32(3), 316-322.

Tuanakotta, T. M. (2016). Audit Kontemporer (2nd ed.). Salemba Empat.

Whittle, A., Carter, C., \& Mueller, F. (2014). 'Above the fray': Interests, discourse and legitimacy in the audit field. Critical Perspectives on Accounting, 25(8), 783-802.

Wuysang, R. V. O., Nangoi, G., \& Pontoh, W. (2016). Analisis penerapan akuntansi forensik dan audit investigatif terhadap pencegahan dan pengungkapan fraud dalam pengelolaan keuangan daerah pada perwakilan BPKP provinsi Sulawesi Utara. Jurnal Riset Akuntansi Dan Auditing “Goodwill," 7(2), 31-53.

Zuberi, O., \& Mzenzi, S. I. (2019). Analysis of employee and management fraud in Tanzania. Journal of Financial Crim, 26(2), 412-431. 